\title{
生物多様性保全の視点から 震災復興を考える
}

鷲谷いづみ

\section{生物多様性条約新戦略計画亡} グリーンインフラストラクチャー

2010 年秋に日本で開催された生物多様性第 10 回締約国会議（COP10）が成功をおさめ、他 の重要文書と共に「新戦略計画」が採択されて から早二年が経過した。新戦略計画は、生物多 様性の現状分析・評価（地球規模生物多様性概 況第 3 版)を踏まえた 2011 年からの計画であり、 2050 年までの長期的なビジョン「自然と共生す る世界」と 2030 年までの目標であるミッショ ンのもと 2020 年までに達成すべき具体的な目 標、「愛知目標」を含む。さらに、2010 年の国 連総会において、日本は、2011 年から 2020 年 までを「国連生物多様性の 10 年」とすること を提案し、採択された。その「10 年」がスター トした直後に東日本大震災に見舞われることと なった。その復興は、生物多様性にかかわる国 際的目標に寄与するように、少なくとも矛盾す ることがないように進められる必要があるだ ろう。

そのためには、ここ 20 年間に生物多様性の 保全と持続可能な利用に関して世界に蓄積した 知見を活用することが必須である。その一つが、 地球温暖化とも関連して近年増加傾向にある災 害に強い地域を空間計画によって実現しょうと する「グリーンインフラストラクチャー」(緑 のインフラ）である。条約の新戦略計画をうけ て策定されたヨーロッパ連合の新しい生物多様 性戦略（2012）では、生物多様性の保全と持続
可能な利用のための基幹的手法として、緑のイ ンフラが位置づけられている。

\section{模範的な緑のインフラとしての さとやま}

そのような緑のインフラの真髄は、生物多様 性を保全し持続可能な形で利用する自然性の高 い空間、例えば広大な干潟、砂丘－後背湿地シ ステム、河川の氾濫原などを、自然災害から社 会を守る空間、メンテナンス・フリーの「干渉 地帯」として確保し、防災のほか多様な生態系 サービスを享受する空間計画である。防災の機 能に限ってみても、従来型のコンクリートの固 い構造物を設置するインフラに比べ、経済的な コストも環境コストも小さく、社会の負担が小 さくてすむ。日本列島に特有の地震や津波だけ でなく、今後は、地球温暖化に伴う異常気象が もたらす風水害がますます激化することが予測 されるが、社会の負担が小さく、同時に多様な 生態系サービスを提供する緑のインフラには、 災害から生命と財産を守るための役割を期待す ることができそうだ。

伝統的な土地利用システムである「さとやま」 には、集落・農地に接して生物資源や水資源を 採取するための空間（ヤマ）がふんだんに存在 した。例えば、河川の汇濫原のヨシ原やオギ原 は、茅場や秝場など、生物資源の採集地として 利用され、そこは、風水害から集落や農地を守 る干渉帯の役割も果たしていた。さとやまは、 
日本における伝統的な緑のインフラであるとも いえるだろう。

沿岸域の干潟や塩生湿地、砂浜に続く砂丘の 上部の松林などは、いずれも多様な自然の恵み を育む場であり、自然資源の採集、レクリェー ション、水質浄化など多様な生態系サービスを 提供していた。とくに、砂丘の内陸側の後背湿 地は、砂丘とつながる生物多様性豊かな空間で あっただけでなく、災害から農地や集落を守 る緩衝地带ともなっていた。活用の仕方次第で 多様な価值を産み出すこれら多義的空間の多く は、「未利用地」と誤解され、一義的な目的で の利用のために開発された。それは、生物多様 性を失わせただけでなく、集落や農地を自然災 害に対して無防備にした。

さとやまのシステムが崩壊した現在、災害を もたらさず、持続的にバランスよく多くの生態 系サービスを享受するための土地利用は、災害 を生じさせる可能性の大きい陸域と水域のあい だの移行帯を自然保護区として、ツーリズムに 利用したり、さとやまの「ヤマ」として、エネ ルギー用バイオマスを含む生物資源の採集地と して活用することによって可能となる。ちなみ に、日本ではいくらでも自然に生えるオギなど のイネ科の大型草本は、バイオマスエネルギー 材料として世界的に注目されている。

\section{自然環境への配慮のない防潮堤建設}

仙台湾には、伝統的利用は廃れているものの、

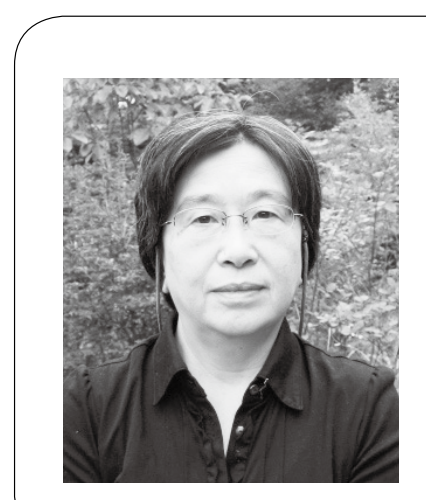

\section{PROFILE}

熟谷いづみ

(わしたに いづみ)

日本学術会議第二部会員、東京大学 農学生命科学研究科保全生態学研究 室教授

専門: 生態学・保全生態学

ある程度幅のある砂浜と連続する砂丘など、日 本では減少が著しい「砂でつながる海と陸の生 態系」が残されている。名取市の広浦では、津 波と地盤沈下の影響で後背湿地が再生し、海か ら連続する自然のシステムが回復した。しかし、 砂浜における堤防の建設が始まり、蘇ったその システムは、砂浜に連続的に設置される防潮堤 の工事によって再び分断される危機に直面して いる。

堤防工事は、例えば、システムが蘇った名取 市広浦から䦥上にかけての一带でみられるよう に、砂浜の防潮堤工事が計画から施工まできわ めて迅速に進められているようである。

海と陸をつなぐ砂のシステムの大きな人工構 造物による遮断は、砂丘の生態系のみならず、 海の生態系にも予測不能な影響を含め、多大な 負の影響を及ぼすことが危惧される。せめて、 計画・施工前に環境アセスメントが実施される べきであろう。

\section{参考文献}

鷲谷いづみ（2012）岩波ジュニア新書 知の航海シリーズ「さ とやま：持続可能な生態系模様」岩波書店

熟谷いづみ (2012) 叢書震災と社会「震災後の生態とどうつ きあうか」岩波書店 